\title{
Reflexie československého práva v „Demokratoch“ Janka Jesenského
}

\author{
Martin Gregor
}

Právnická fakulta, Univerzita Komenského v Bratislave

Kontaktni e-mail:martin.gregor@flaw.uniba.sk

\section{Reflections of Czechoslovak Law in the "Democrats" by Janko Jesenský}

\begin{abstract}
:
The famous Slovak writer Ján Jesenský published in 1934 and 1938 the two-volume novel "Democrats", in which he pointed out the problems of Czechoslovak democracy in practice. Besides the ingenious description of the bureaucracy, the detailed depiction of the provincial establishment and its functioning within the Slovak conditions in the years 1927-1938, he also focused on projecting the real life of political parties, political intrigues and manoeuvres. The presented study aims to analyse this work from the point of view of legal history, trying to create a more comprehensive view of the law of the First Republic from the non-legal sources. The focus lies on comparing the legal situation with its literary adaptation. Apart from the analysis of this novel and the life of the author, the article further deals with some selected issues of the provincial establishment and the status of parliamentarianism in the Czechoslovak Republic.
\end{abstract}

\section{Keywords:}

Czechoslovak Republic (1918-1938); public administration in the First Czechoslovak Republic; politics in the First Czechoslovak Republic; provincial establishment; elections to the National Assembly; prohibition of binding mandate

\section{Kl’účové slová:}

Československá republika (1918-1938); verejná správa v prvej ČSR; politika v prvej ČSR; krajinské zriadenie; vol'by do Národného zhromaždenia; zákaz imperatívneho mandátu

DOI: $10.14712 / 2464689 X .2018 .39$

Financování: Príspevok je výstupom z Grantu Univerzity Komenského č. UK/14/2018. 
Dňa 28. 10. 2018 uplynulo sto rokov od vzniku spoločného štátu Čechov a Slovákov. Prvá Československá republika sa prihlásila k hodnotám demokracie a parlamentarizmu. ${ }^{1}$ V nových pomeroch sa začal na Slovensku rýchlo rozvíjat' svojbytný politický život. Utvorili sa podmienky pre rozvoj občianskej spoločnosti. ${ }^{2}$ Napriek nespornému pokroku vo všetkých sférach života spoločnosti sa však prvá republika borila aj s určitými problémami.

Táto štúdia sa dotkne skôr jej odvrátených stránok. Za predmet svojho skúmania si zvolila druhú čast’ románu „Demokrati““ od Janka Jesenského, ktorá býva literárnymi teoretikmi definovaná ako prozaická encyklopédia poprevratového spoločenského života sui generis. ${ }^{3}$ Po činorodom období slovenského realizmu, ktorý sa sústred'oval na kritické vykreslenie t’ažkých podmienok života v monarchii, len Ján Jesenský dokázal presvedčivo reagovat' na postupnú zmenu pomerov a vo svojej prozaickej tvorbe sa pokúsil zachytit' určitý posun $\mathrm{v}$ živote mestského človeka a slovenskej inteligencie počas trvania prvej ČSR. ${ }^{4}$ Poukázal bezprostredne, ale o to kritickejšie, na nefunkčnost' byrokracie, nekalú prax politických strán, volebné machinácie a d'alšie javy disharmónie medzi teóriou a praxou v ústavnom a správnom práve prvej ČSR. ${ }^{5}$ Nenadarmo autor naznačil, že román pojednáva skôr o ,pseudodemokratoch“ a terajší názov zvolil len preto, aby týmto skupinám privel'mi nekrivdil. ${ }^{6}$

Umenie sa pokúša poskytnút’ určitú interpretáciu spoločenskej reality. Samotné právo nachádza svoj odraz v kultúre a v niektorých prípadoch dokonca figuruje ako jeden z inšpiračných zdrojov umeleckých diel. Skúmanie práva prostredníctvom krásnej literatúry umožňuje lepšie pochopit’ jeho existenciu v bežnom živote a zároveň dáva priestor pre diskurz o zložitých otázkach etiky, morálky a spravodlivosti. ${ }^{7}$ Nespútaný duch umenia dokáže niekedy najlepšie pomenovat' nedostatky právneho systému. To platí obzvlášt' o dielach, ktoré sa svojou povahou usilujú verne zobrazit' ducha svojej doby. Preto sa tento článok pokúsi analyzovat' Jesenského „Demokratov“ z právnohistorického hl'adiska, pričom okrem všeobecnej charakteristiky tohto diela sa pokúsi porovnat' jednotlivé pasáže o práve a politike s platným právnym stavom v prvej Československej republike.

1 GÁBRIŠ, T. Právne vyjadrenie hodnôt novovytvorenej ČSR (1918). In: Dny práva - 2008 - Days of Law. Brno: Masarykova Univerzita, 2008, s. 439.

2 GÁBRIŠ, T. - ŠVECOVÁ, A. Dejiny štátu, správy a súdnictva na Slovensku. Plzeň: Aleš Čeněk, 2009 , S. 146

3 ŠMATLÁK, S. Dejiny slovenskej literatúry II.: 19. storočie a prvá polovica 20. storočia. Bratislava: Literárne informačné centrum, 2001, s. 269.

4 ROZNER, J. Jesenského Demokrati. In: MATUŠKA, A. - JESENSKÁ, Z. (eds.). Janko Jesenský v kritike a spomienkach: Sbornik. Bratislava: Slovenské vydavatel'stvo krásnej literatúry, 1955, s. 507-508; Podobne: CHORVÁTH, M. Demokrati (doslov). In: JESENSKÝ, J. Spisy V.: Demokrati. Doslov a poznámky napisal Michal Chorváth. Bratislava: Slovenské vydavatel'stvo krásnej literatúry, 1961, s. 473.

5 Menej známym autorom, ktorý sa venoval mimoriadne podobným témam politiky a administratívy v období prvej Československej republiky, bol napr. Elo Šándor, tvorca Sváka Ragana (ŠÁNDOR, E. Zákonodarci. Bratislava: Universum, 1936; ŠÁNDOR, E. Byrokrati alebo slasti a strasti obecných zriadencov na Slovensku. Liptovský sv. Mikuláš: Tranoscius, 1945). V týchto románoch však absentuje práve Jesenského osobná skúsenost'.

6 List J. Jesenského A. Mrázovi zo dňa 9. 10. 1934. Pozri: PETRUS, P. (ed.). Vzájomná korě̌pondencia Janka Jesenského s Andrejom Mrázom. Martin: Matica slovenská, 1981, s. 46.

7 ŠKOP, M. ... právo, jazyk a príběh. Praha: Auditorium, 2013, s. 21. Podobne: KLUSOŇOVÁ, M. Hnutí právo a literatura koncem 20. a na počátku 21. století. Brno: Masarykova univerzita, 2015, s. 20. 


\section{Právnik ako umelec, „Demokrati““ ako román}

Ján Jesenský (1874-1945) vyštudoval právo na Právnickej akadémii v Prešove a doktorát získal na univerzite v Kluži. Pôsobil ako advokát v Bánovciach nad Bebravou. ${ }^{8}$ Prvá svetová vojna však navždy zmenila jeho osud. V dôsledku svojej angažovanosti v ruskom zajatí sa po jej skončení stal vysokým úradníkom v službách tzv. prvej republiky. Od mája 1919 pôsobil ako župan Gemersko-malohontskej župy. Potom, čo nadobudol účinnost’ československý župný zákon (č. 126/1920 Zb. z. a n.), bol vymenovaný za nitrianskeho župana, hoci sa pre nové správne členenie skôr vžil termín vel’župy, v dôsledku ich väčšej rozlohy oproti ich uhorským predchodcom. Po zrušení župného zriadenia a rozdelení územia ČSR na štyri krajiny - Českú, Moravskosliezsku, Slovenskú a Podkarpatskoruskú - (zákonom č. 125/1927 Zb. z. a n.) prešiel na Krajinský úrad do Bratislavy, kde od roku 1929 zastával funkciu krajinského viceprezidenta až do svojho predčasného penzionovania v roku $1935 .{ }^{9}$

Posledné pôsobisko podnietilo Jesenského k napísaniu dvojzväzkového románu „Demokrati“. Svojou povahou ide o tzv. diskrétnu (skrytú) autobiografiu. ${ }^{10}$ Politické skúsenosti a právne motívy však tvoria len čast' Jesenského vyznania, ktoré je natol'ko intímne, že autor pokladal za nevyhnutné, aby ho prekryl d’alšími konceptuálnymi rámcami. V postave bankového direktora Rozvalida, ktorý sa dostal na mizinu kvôli tomu, že „,neprotestoval“ zmenku vplyvných politikov, zobrazil osud svojho vlastného otca Jána Jesenského-Gašparé. Viackrát kandidoval za poslanca do Uhorského snemu ako prívrženec Slovenskej národnej strany, v dôsledku čoho sa výrazne zadlžil. Hoci istý vrcholný predstavitel' tejto strany najskôr sl'úbil, že sa bude spolupodiel'at' na volebných výdavkoch, napokon k tomu nedošlo a rodinný majetok Jesenských bol predaný na dražbe. ${ }^{11}$

Osobnost' mladého úradníka Dr. Jána Landíka, ktorý stmel’uje jednotlivé časti deja, je naopak zosobnením autorových vlastných názorov a vízií. Táto postava zdiel’a Jesenského životný ideál, skrze ktorého hodnotí v románe iných l'udí. No názory vyzretého spisovatel'a už neboli prejavom mladíckych túžob po morálnych maximách, ale skôr ich možno charakterizovat' zistením, že priebeh života núti l'udí ku kompromisom. ${ }^{12}$ Landík je preto vo svojej podstate pasívnym charakterom, ktorý prijíma tento svet ako daný, bez potreby prevratne ho menit', no napriek tomu si želá, aby medzi l'ud'mi vládla slušnost' a morálne ohl'ady, pričom tieto ideály nezrádza pre vidinu bohatstva a povýšenia. ${ }^{13}$

Napriek tomu nemožno bagatelizovat’ ani prvky práva a politiky, ktoré našli v tomto románe svoje odzrkadlenie. Pravdivá životná skúsenost' právnika a vysokého úradníka

$8 \quad$ PETRUS, P. Janko Jesenský: Nepokorený smiech a vrásky sveta. Martin: Osveta, 1982, s. 47. Pozri tiež: ROSENBAUM, K. a kol. Encyklopédia slovenských spisovatel’ov. Prvý zväzok (A-O). Bratislava: Obzor, 1984, s. 283.

9 KALÁČ, F. Župan a krajinský viceprezident Dr. Ján Jesenský. In: MATUŠKA, A. - JESENSKÁ, Z. (eds.). Janko Jesenský v kritike a spomienkach. Sbornik. Bratislava: Slovenské vydavatel'stvo krásnej literatúry, 1955, s. 230 a nasl.

10 MIKULOVÁ, Marcela. Transformácia autobiografie a populárnej literatúry v Jesenského románovom koncepte. Slovenská literatúra: revue pre literárnu vedu, 2008, roč. 55, č. 2-3, s. 93.

11 MIKULOVÁ, M. Janko Jesenský. In: Kapitoly zo slovenského realizmu: dejiny, medailóny, štúdie, interpretácie. Bratislava: Univerzita Komenského, 2010, s. 219. Podrobnejšie aj: JESENSKÝ, F. Z rodičovského domu. In: MATUŠKA, A. - JESENSKÁ, Z. (eds.). Janko Jesenský v kritike a spomienkach: Sborník. Bratislava: Slovenské vydavatel'stvo krásnej literatúry, 1955, s. 57-60.

12 MIKULOVÁ, M. Janko Jesenský: Demokrati (1934, 1938). In: Sondy: Interpretácie klúčových diel slovenskej literatúry 20. storočia. Bratislava: Kalligram, 2014, s. 164-165.

13 ROZNER, c. d., s. 545. 
ČSR našla svoje vyjadrenie v množstve drobných čiastočiek poznatkov a úvah, ktoré obohacujú náš náhl'ad na právo prvej republiky. Snád' nebolo len lichotením nakladatel'a, ked' Andrej Mráz napísal Jesenskému o tomto románe: ,je v n̆om tol'ko pravdy, tol'ko verného odzrkadlenia našich pomerov a všetko podané tak ucelene...". ${ }^{14}$ Autorova výpoved' bola naozaj natol'ko aktuálnou a presnou, že román „Demokrati“ je stále pokladaný za politické, ba dokonca ideologické dielo. ${ }^{15}$ Literárni kritici mu dokonca vytkli, že zobrazeniu politických inštitúcií prikladal autor väčšiu váhu než vypracovaniu charakterov. ${ }^{16} \mathrm{Z}$ toho dôvodu možno pokladat' predmetné dielo za vynikajúci podklad pre hlbší právny rozbor.

Viacerí politici a úradníci z románu sú zosobnením aktívnych predstavitel’ov vtedajšieho verejného života. Ich opis je natol'ko plastický a vol'ba priezvisk tak symbolická, že niet pochýb, koho satira zasahuje. ${ }^{17} \mathrm{~V}$ postave démonizovaného klerikálneho kňaza Antona Turčeka, ovládajúceho polovicu Bánoviec nad Bebravou našla odzrkadlenie postava samotného Jozefa Tisa. ${ }^{18}$ Ten „už dávno derie krpce na politických cestách, je stálym poslancom a raz bol aj ministrom“ (v III. vláde A. Švehlu bol ministrom zdravotníctva). „Ministerstvo prestalo, ale titul, sláva, autorita zostala... Spomeňme ešte tie čestné občianstvá a vydané o nich čestné diplomy, visiace na fare a prístupné iba host’om, ktorí navštívili pána ministra mimo službu."19

Sám Jesenský v románe vystupuje ako viceprezident Dr. Zimák (odvodené od zimy ako Jesenský od jesene). Kornel Stodola bol predlohou pre senátora Záčina (záčin je čast'ou stodoly), ktorému sa ešte vtedy vyčítalo, že počas svetovej vojny pôsobil vo Viedni a v rámci vysokých dvorských kruhov sa pokúšal riešit’ slovenskú otázku („,bývalý dôverník rakúskych arcikňažien“"). ${ }^{20}$ Ctižiadostivý Žalud', zdravotnícky referent krajinského výboru, nebol nikto iný ako neskorší viceprezident Igor Dula (žalud' odzadu), ktorý v kresle nahradil predčasne penzionovaného Zimáka. ${ }^{21} \mathrm{~V}$ postave advokáta Gábriša, ktorý úspešne zastupoval mad'arského aristokrata v spore o pät’desiat miliónov korún sa však ukrýva slávny bratislavský právnik a prívrženec agrárnej strany Pavol Fábry, o ktorom kolovala klebeta, že si nechal doviezt' lietadlom halušky z Bratislavy až na Riviéru (detailne zachytenú aj v románe). ${ }^{22}$

14 List A. Mráza J. Jesenskému zo dňa 10. 12. 1937. Pozri: PETRUS, Vzájomná korešpondencia Janka Jesenského s Andrejom Mrázom, s. 87.

15 MIKULOVÁ, Marcela. Transformácia autobiografie a populárnej literatúry v Jesenského románovom koncepte (pokračovanie). Slovenská literatúra: revue pre literárnu vedu, 2008, roč. 55, č. 4, s. 249.

16 ROZNER, c. d., s. 506.

17 HALUZICKÝ, B. Rozpomienky na Janka Jesenského. In: MATUŠKA, A. - JESENSKÁ, Z. (eds.). Janko Jesenský v kritike a spomienkach: Sbornik. Bratislava: Slovenské vydavatel'stvo krásnej literatúry, 1955, s. 267.

18 CHORVÁTH, c. d., s. 511.

19 JESENSKÝ, J. Demokrati. In: Próza Janka Jesenského. Bratislava: Tatran, 1977, s. 724-725.

20 MIKULOVÁ, Transformácia autobiografie a populárnej literatúry v Jesenského románovom koncepte (pokračovanie), s. 239-240. Porovnaj text: JESENSKÝ, Próza Janka Jesenského, s. 588.

21 Formálnym dôvodom pre Zimákovo odvolanie bolo dosiahnutie príslušného veku podl’a legionárskeho zákona (vo svojej podstate šlo o výhodu).

22 KERECMAN, P. Advokáti Davisti: Ján Poničan (4. čast'). Bulletin slovenskej advokácie, 2016, roč. 22, č. 3, s. 61 . 
Predkladaná analýza tohto románu sa sústred’uje najmä na druhý diel Demokratov²3 po vymenovaní Landíka za úradníka Krajinského úradu. Jednou z hlavných postáv sa v tejto časti stáva Landíkov príbuzný, vplyvný bratislavský advokát Dr. Juraj Petrovič, ktorý je zároveň členom krajinského zastupitel'stva a krajinského výboru. Popri relatívne detailnej deskripcii nuáns práce krajinského poslanca sa Jesenský zameral najmä na Petrovičovo úsilie, aby bol zvolený za člena Národného zhromaždenia v nadchádzajúcich vol'bách. K dosiahnutiu tohto ciel’a viedli nielen zákulisné intrigy pri zostavovaní kandidátskej listiny agrárnej strany, ale aj samotná volebná kampaň - kortešačky - na dedinách a v mestách. ${ }^{24} \mathrm{~V}$ závere románu sa Petrovičovi podarilo získat' dôveru voličov a napokon zasadol do lavíc Národného zhromaždenia aj napriek intrigám neúspešných straníkov. Samozrejme, dej románu je komplexnejší, ba dlhé obdobie bol kritizovaný pre zobrazenie náklonnosti úradníka Landíka k slúžke Anne ako prvku tzv. červenej knihovne oproti otázkam politiky a moci, typickej súčasti vysokého žánru. ${ }^{25}$

Toto spojenie je však paradoxne len variáciou na tému rovnosti, ktorá sa vinie románom: „Zákon je kaša, do ktorej dvaja pl’ujú: zákon a život. Podl’a zákona je osobná sloboda zaručená, a podl'a zákona ju možno vziat'. Podl'a zákona je sloboda slova, a podl'a zákona musíte držat' jazyk za zubami... Podl'a zákona je rovnost', a podl'a zákona jej niet, ale sú stavy a triedy, sú nadriadení a podriadení...".26 tak sa Landík aj v románe bránil proti výčitkám svojho nadriadeného, že nadbiehanie obyčajnej slúžke je porušením § 24 Služobnej pragmatiky, ${ }^{27}$ ktorý je v samotnom texte doslova citovaný: „Úradník má v službe i mimo služby dbat' na stavovskú vážnost'... a všetkého sa vyvarovat', čo by mohlo zl'ahčit' úctu a dôveru, ktorú jeho postavenie vyžaduje.“

\section{Krajinské zastupitel'stvo a krajinský výbor z pohl'adu Janka Jesenského (literárne humoresky o správnom práve)}

Dr. Petrovič vykonával popri advokácii aj úrad „krajinského poslanca“, čo znamená, že bol členom krajinského zastupitel'stva Slovenskej krajiny podl'a zákona č. 125/1927 Zb. z. a n. o organisaci politické správy (tzv. organizačný zákon). ${ }^{28}$

Od okamihu účinnosti tohto zákona sa presadila úplná jednota verejnej správy v celej Československej republike. Táto reforma nahradila dovtedajší pokus o presadenie župného systému podl'a zákona č. 126/1920 Zb. z. a n., ktorý však nebol v Českých krajinách a na Podkarpatskej Rusi účinný (čl. 2 župného zákona ustanovoval, že deň začatia činnosti župných a okresných úradov, vrátane ich miestneho vymedzenia, určí vláda nariadením.

23 Jesenský chcel druhý diel románu pôvodne nazvat’ „Starosti pána poslanca“, prípadne „Diktátori“. Pozri: PETRUS, Vzájomná korešpondencia Janka Jesenského s Andrejom Mrázom, s. 15.

24 K téme volebnej kampane v slovenskej literatúry pozri aj Kalinčiakovu Reštavráciu, týkajúcu sa volieb župných funkcionárov v Uhorsku (KALINČIAK, J. Reštavrácia: obrazy z nedávnych čias. Bratislava: Mladé letá, 1961).

25 MIKULOVÁ, Sondy: Interpretácie klúčových diel slovenskej literatúry 20. storočia, s. 141.

26 JESENSKÝ, Próza Janka Jesenského, s. 341.

27 Zákon č. 15/1914 ř. z., o služobnom pomere štátnych úradníkov a štátnych sluhov, ktorého platnost’ rozšíril $\S 2$ zákona č. 269/1920 Zb. z. a n. aj na Slovensko.

28 HENDRYCH, D. a kol. Správní právo: obecná část. 6. vydání. Praha: C. H. Beck, 2006, s. 133. 
Nariadením vlády RČS č. 310/1922 Zb. z. a n. sa však župný zákon de facto začal vzt’ahovat' iba na územie Slovenska, teda na župy XV-XX). ${ }^{29}$

Napriek tomu nešlo o úplne radikálnu zmenu, ked’že krajinské zriadenie do značnej miery vychádzalo z jeho župného náprotivku (zákon o organisaci politické správy bol formálne len novelou župného zákona). Inštitúty župného zastupitel’stva a výboru boli vo vel'kej miere upravené analogicky s krajinským zastupitel'stvom a výborom. ${ }^{30}$ Jediným podstatnejším dôsledkom zjednotenia verejnej správy bolo zrušenie Ministerstva s plnou mocou pre správu Slovenska, ked’že jeho pôsobnost' bola prenesená na Krajinský úrad v Bratislave, čím možno zdôraznit' dôležitost' nového usporiadania. ${ }^{31}$

\section{Členstvo v krajinskom zhromaždení}

Podl'a zákona o organisaci politické správy sa v zastupitel'stve Slovenskej krajiny schádzalo 54 poslancov. Dve tretiny boli volené v súlade so zásadou pomerného zastúpenia podl'a zákona č. 330/1920 Zb. z. a n. (pôvodne zákon o volbách župních zastupitelstev a okresních výborů) v znení zákona č. 126/1927 Zb. z. a n. o volbách zemských a okresních zastupitelstev. Zvyšní členovia (t. j. na Slovensku 18 poslancov) boli menovaní vládou ako odborníci.

Pri formovaní tohto konceptu bol zákonodarca vedený princípmi demokratickosti ${ }^{32}$ a odbornosti ${ }^{33}$ krajinskej správy súčasne. Menovacie právo bolo chápané ako korektív výsledkov volieb v prospech vyššej špecializácie zastupitel'stva. ${ }^{34}$ Zároveň sa pokladalo za bariéru zbytočnej politizácie regionálnych telies, ktoré neplnili politické funkcie ( $\$ 30$ ods. 2 in fine novelizovaného župného zákona nedovol'oval podávat' návrhy politického

29 Pozri k tomu: BAXA, B. Veřejná správa na Slovensku. Brno: Čs. a S. Právník, 1936, s. 6-7. K teoretickým diskusiám, či sa župný zákon ako taký vôbec mohol vzt’ahovat' na Podkarpatskú Rus, pozri Weyrov negatívny názor (WEYR, F. Československé právo správní. Část obecná. Brno: Právník, 1922, s. 133) a Laštovkove sčasti pozitívne stanovisko (LAŠTOVKA, K. K otázce místní působnosti župního zákona. Právny obzor, 1922, roč. 5, s. 193.)

$30 \quad$ Okrem zrušenia žúp a ich nahradenia krajinami boli rozdiely viac-menej kozmetické. Postavenie župana prevzal krajinský prezident, ,župné“ zastupitel'stvo a „župný výbor“ sa stali „krajinskými“. Diferencovane bola upravená napr. problematika zastupovania župana (kr. prezidenta) pri predsedaní župnému (krajinskému) výboru. Kým župan ho mohol zverit’ niektorému z členov výboru alebo aj úradníkovi župného úradu, po novelizácii sa v tomto prípade obracal krajinský prezident na svojho viceprezidenta (§ 27). Zdôrazňuje to: HOETZEL, J. Československé správni právo. Část všeobecná. Praha: Melantrich, 1937, s. 213.

31 Porovnaj: § 1 vládneho nariadenia č. 94/1928 Zb. z. a n. o presune pôsobnosti ministra s plnou mocou pre správu Slovenska. Na porovnanie konštrukcie tohto úradu pozri: LAŠTOVKA, K. Plná moc ministra s plnou mocí pro správu Slovenska. In: Sborník věd právnich a státních, roč. 22: Pocta Heyrovskému. Praha: Bursík \& Kohout, 1922, s. 290.

32 Krajinské zriadenie v ČSR nikdy nedosiahlo úroveň tzv. vrchnostenskej samosprávy podla pruského alebo pôvodného uhorského vzoru, v rámci ktorého by občania mohli volit’ vo vol'bách napr. aj krajinského prezidenta (predtým župana). Preto zastupitel'stvá ostávali jediným prvkom samosprávy - zastúpenia občanov - v krajine. Pozri: BAXA, B. Zákon o župním zřizení a jeho nedostatky (otisk z České Revue). Praha: Státovědecká společnost, 1922, s. 15.

33 Aby sa mohlo očakávat' zvolenie rozumnejších a erudovanejších osobností do krajinského zastupitel'stva, zákonodarca $\mathrm{z}$ tohto dôvodu sprísnil podmienky aktívneho volebného práva do krajinských zastupitel'stiev z 21 na 24 rokov a z 3-mesačného na ročný pobyt v krajine. Pozri dôvodovú správu k § 1 zákona č. 126/1927 Zb. z. a n.

34 HOETZEL, Československé správní právo, s. 212. Podobne: POVAŽAN, M. Náčrt vývoja verejnej správy na Slovensku (1918-1939). Historia et Theoria Iuris, 2017, roč. 9, č. 1-2, s. 138. 
charakteru). ${ }^{35}$ Napokon zastupitel'stvá boli charakterizované ako poradné zbory (pozri $§ 59$ novelizovaného župného zákona), ktoré disponovali normatívnou právomocou len v prípadoch ustanovených zákonom. Mali plnit’ úlohu kvalifikovaných zborov pre posudzovanie hospodárskych a sociálnych otázok krajiny, neboli zákonodarným telesom, preto ani menovanie odborníkov nemohlo byt' nedemokratické. ${ }^{36}$

Uvedený model bol na celoštátnu úroveň prevzatý z osobitostí župnej správy na Slovensku, kde sa menovacie právo pripustilo ako výnimočný inštitút už podla župného zákona z roku 1920. So zretel’om na zvláštne pomery jednotlivých žúp mohla vláda vymenovat' max. jednu tretinu zastupitel'ského zboru (na základe $§ 76$ zákona č. 330/1920 Zb. z. a n. vznikla pochybnost', či túto právomoc nemá minister vnútra, avšak v každom prípade vláda si mohla túto vec vyhradit', aj keby tomu tak bolo). ${ }^{37}$

Nároky na kvalifikáciu vymenovaných odborníkov neboli bližšie upravené. Z toho vyplýva, že bolo predovšetkým úlohou vlády, aby posúdila ich odbornost' po formálnej a materiálnej stránke. Za ustanovenie odborníkov do krajinských zastupitel'stiev však niesla iba politickú zodpovednost'. ${ }^{38} \mathrm{O}$ vymenovaní jednotlivých špecialistov vláda rozhodovala v pléne v súlade $\mathrm{s} \S 81$ písm. c/ Ústavnej listiny, pričom materiálne vychádzala predovšetkým z návrhov ministra vnútra a príslušného krajinského prezidenta. Pri ich výbere sa nemala riadit' politickou príslušnost'ou určených osôb.

Janko Jesenský hlbšie analyzoval práve tento moment. Naznačuje nielen to, že pred ozajstnou odbornost'ou dostávali často prednost' politické nominácie, ale aj tú skutočnost', že uplynul relatívne dlhší čas, kým sa politické strany zjednotili na konkrétnych menách. Tieto osoby „už nevolil národ, ale strana a menovala ich vláda. Takéto menovanie trvalo vždy dlhšie ako vol'by. Niekedy i pol roka. Nie azda preto, ako sa opozičné noviny posmievali, že musí stiect' vel'a vody dolu Váhom, kým z predsedu dedinského konzumu vyrastie finančná kapacita, $\mathrm{z}$ farára odborník v priemysle, $\mathrm{z}$ holiča slávny znalec cirkevných vecí... ale preto, že sa hl'adal kl’úč, a nemohol sa dlho nájst' taký, ktorý by sa hodil do každej dierky na zámkach magazínov straníckych skladov, kde ešte mnohí výtečníci ležali úhorom a bolo ich treba povyt'ahovat' pre ich dôležitost'... To nie je ako blesk, to je velikánske klbko, ktoré sa nekonečne t’ahá, kým sa zhačkuje také zastupitel'stvo.“39

V praxi tak menovacie právo nielenže nedosiahlo svoj účel, ale naopak poslúžilo k presadeniu stavu, ktorému sa jeho idea snažila zabránit'. Odborníci boli menovaní na základe straníckych kritérií. Z týchto dôvodov menovacie právo tvrdo odsúdila vtedajšia opozícia aj neskoršia, socialistická doktrína. Pokladala ho za spôsob manipulácie so zložením

35 Pôvodné znenie $\S 30$ župného zákona explicitne a úplne vylučovalo politické veci z pôsobnosti zastupitel'stva. Hoci po novele sa pripúšt’alo vedenie „,politických rozhovorov“ na pôde zastupitel'stva a reštrikcia sa začala vzt'ahovat' iba na podávanie návrhov v politických veciach, účel tohto ustanovenia ostal nezmenený. Došlo iba k lepšiemu uchopeniu normatívneho stavu, ked’že zákonodarca si bol vedomý, že politické diskusie nemožno vylúčit' ani pri odbornom rokovaní o hospodárskych a sociálnych otázkach. ŘÍHA, J. (ed.). Organisace politické správy v republice Československé. Praha: Československý kompas, 1928, s. 215. A contrario: WEYR, Československé právo správní, s. 134.

37 LAŠTOVKA, K. Zákon župni: Zákon ze dne 29. února 1920 č. 126 Sb. zák. a nař. opatřený výkladem. Bratislava: Právnická Jednota, 1925, s. 91.

38 ŘÍHA, $c$. d., s. 214.

39 JESENSKÝ, Próza Janka Jesenského, s. 738. 
zastupitel'stiev, realizované v prospech vládnucich strán a to aj za cenu znehodnotenia hlasov voličov o jednu tretinu. ${ }^{40}$

Menovacie právo sa však naozaj stalo kl'účovým aspektom kreovania nových zastupitel'stiev. ${ }^{41}$ Ministerstvo vnútra explicitne požadovalo, aby návrhy na odborníkov boli predkladané po rokovaní s predstavitel'mi politických strán, a zoznam navrhnutých kandidátov mal byt' kategorizovaný podl’a ich príslušnosti k dotyčným stranám. Krajinský úrad dokonca mohol ministerstvu podat' správu, v ktorej navrhol určité usporiadanie mandátov podl'a svojich predstáv. ${ }^{42}$

\section{Členstvo v krajinskom výbore}

Advokát Petrovič nebol len obyčajným krajinským poslancom, ale aj členom krajinského výboru. V priebehu deja autor popisuje, kol'ko energie vkladal Petrovič do výkonu tohto postu. Študoval programy, vymýšl’al prejavy a interpelácie, popritom vybavoval finančnú podporu pre peknú mladú vdovu. Popri krajinskom prezidentovi, „ktorý s Petrovičom ruka v ruke pracuje“, predstavoval krajinský výbor ekvivalent výkonnej moci na regionálnej úrovni.

Skladal sa z dvanástich členov a rovnakého počtu náhradníkov, ktorých volilo spomedzi seba krajinské zastupitel'stvo s prihliadnutím na pomery politických strán v zastupitel'stve. ${ }^{43} \mathrm{O}$ členstvo vo výbore sa však mohli uchádzat' len zvolení poslanci. ${ }^{44}$ Agenda krajinského výboru bola rozdelená do skupín, ktorú mali zverenú vždy dvaja členovia výboru: referent a jeho náhradník. Petrovičovi pripadla úloha, aby pôsobil ako koreferent národohospodárskych záležitostí. Svojou autoritou hravo prevýšil svojho kolegu, koreferenta Srdienka, ktorý sa obmedzoval na prejavovanie súhlasu so svojím dominantnejším spolupracovníkom.

Referenti predstavovali v krajinskom výbore protiváhu voči úradníckemu zboru. Stretávali sa s nimi v odborných diskusiách. Kým prvá skupina sa usilovala presadit' vlastné politické záujmy, entita byrokratov sa striktne pridržiavala právnych predpisov, čím spomal'ovala realizáciu predstáv referentov. „To sú všetko len úradné oči, ktoré hl'adia lornetom paragrafu. Na veci treba hl'adiet' očami strádajúceho l’udu, s porozumením. Úradníci sú úradníci a l'ud je l'ud... V jednom tábore spravujú sa úradníci protivňou na rozgajdanost', neporiadok. V druhom tábore panuje protiveň na závislost', zviazanost', kontrolu všelijakých tých motúzových paragrafov... Z jednej strany však stavajú most úradníci, z druhej strany občania-laici. Na spoločných poradách sa radia, ako ho stavat'... Na to je výbor, zastupitel’stvo, kde sa tie dva tábory schádzajú a presviedčajú navzájom.“"45

$40 \quad$ BIANCHI, L. Samospráva a občianske slobody v buržoáznej ČSR. Bratislava: Slovenské vydavatel'stvo politickej literatúry, 1954, s. 8-10. (Podobne kritizovaný bol aj zákaz predkladania politických návrhov.). Pozri tiež: RATTINGER, B. Protilidovost předmichovské, tak zvané politické správy v okresech a zemích. Právník, 1954, roč. 93, č. 3, s. 139-141.

41 Stranícka povaha odborníkov vyplývala aj zo spôsobu vol’by členov krajinského výboru, v rámci ktorých každý menovaný člen musel písomne vyhlásit', s akou politickou stranou bude volit', t. j. oproti pôvodnému návrhu pri vol'bách netvorili samostatný blok v zastupitel'stve. Pozri: ŘíHA, c. d., s. 394-396.

42 SCHELLE, K. Vývoj české verejné správy. Ostrava: Key Publishing, 2007, s. 303.

43 HOETZEL, Československé správní právo, s. 213. Priebeh vol’by do krajinského výboru upravovali § 54-57 zákona o volbách zemských a okresních zastupitelstev č. 330/1920 Zb. z. a n. v znení zákona č. 126/1927 Zb. z. a n.

44 SCHELLE, c. d., s. 292.

45 JESENSKÝ, Próza Janka Jesenského, s. 505. 
No kým za úradníkom stál „len akýsi papier-dekrét, ktorým bol vymenovaný akýmsi úradom...", za koreferentom „hrmel a burácal hlas národa“, ktorý si ho do politiky vyvolil. No nielen preto mali koreferenti pri rokovaniach lepšiu pozíciu. V prípade neochoty stačilo členovi krajinského výboru oslovit’ príslušného ministra, ktorý „,na úradníka pôsobí ako strašiak“. ${ }^{46}$ Táto možnost' postačovala na to, aby úradníci úslužne načúvali koreferentovým názorom a zásadne sa prikláňali na jeho stranu. A tak ,slniečko hreje, zoblieka mundúr, rozväzuje tkanice paragrafov... žiadatel' sa tiež zohrieva, nájde pomocnú priatel'skú ruku, ktorá dáva, dáva a dáva, i ked” nie zo svojho, ale zato tým radostnejšie. “47 Jesenský sa pokúšal vyjadrit', že hoci úradníci väčšinou nesúhlasili s politickými víziami poslancov, ba usilovali sa poukázat' na nedostatky ich návrhov, v dôsledku ich závislosti na vôli členov krajinského výboru bol ich odpor len iluzórny, lebo napokon sú len „vykonávatel'mi vôle l'udu“, zato hlasom l'udu je poslanec.

V dôsledku toho bolo nevyhnutné, aby sa jednotliví referenti vo výbore dohodli medzi sebou a našli pre svoje návrhy dostatočnú podporu: „(Referenti) skôr bojujú medzi sebou. Ale nebojujú ani medzi sebou. Skôr sa vzájomne podporujú. Pred každým prípadným bojom je najprv diplomatické pokonávanie, ktoré sa vždy skončí úspechom, “48 lebo referenti zásadne podporovali každý návrh svojich kolegov, aby sa dočkali podpory aj pre tie vlastné. To bolo aj motívom, prečo sa Petrovič nepostavil proti priznávaniu podpôr najrozličnejším kultúrnym a sociálnym ústavom. Napriek tomu, že sa mu zdali prehnané a poškodzujúce záujmy krajiny, nemohol sa voči nim postavit', lebo tým by si popudil ostatných referentov, ktorí by sa následne aj $\mathrm{k}$ jeho návrhom stavali rovnako skepticky. Kvôli tomu museli ustúpit' do úzadia jeho úvahy o tom, že ,človek nevie, či pre to množstvo všelijakého platenia sú l'udia nútení žiadat' podpory, či pre stále podpory je nútený štát, krajina, okres pýtat' od svojich poplatníkov viac a viac.“49

Podobným spôsobom Jesenský s l'ahkost'ou opísal zložitý mechanizmus fungovania krajinského výboru. Okrem členov výboru - „výborníkov“ - participovala na zasadnutiach tohto útvaru aj byrokratická zložka. Už v rámci župného zriadenia sa rokovaní župného výboru zúčastňovali dokonca všetci úradníci župného úradu, ktorí mali oprávnenie samostatne vybavovat' záležitosti spadajúce do pôsobnosti župného zastupitel'stva. ${ }^{50}$ Spravidla išlo o vedúcich dotknutých oddelení župného úradu (najmä tzv. decernentov). ${ }^{51}$ Podl'a ust. § 14 Rokovacieho poriadku pre župné výbory (vládne nariadenie č. 26/1924 Z. z. a n.) mali byt' na schôdze župného výboru pribratí všetci referenti vo veciach, o ktorých sa bude podl'a programu rokovat'.

Po vytvorení krajinskej štruktúry sa malo za to, že podl'a ust. § 26 novelizovaného župného zákona bol krajinský prezident oprávnený určit', ktorí úradníci krajinského úradu sa budú zúčastňovat' rokovania krajinského výboru. Ťažko uchopitel'né znenie dotknutého ustanovenia však na podstate veci nič nemenilo. Podl'a ust. § 11 Rokovacieho poriadku pre

\footnotetext{
46 Tamtiež, s. 508.

47 Tamtiež, s. 506.

48 Tamtiež, s. 506.

49 Tamtiež, s. 513.

50 § 26 zákona č. 126/1920 Zb. z. a n. o zrízení župních a okresních úradů v pôvodnom znení.

51 LAŠTOVKA, Zákon župní, s. 137.
} 
krajinské výbory ${ }^{52}$ mali byt' na rokovania úradného výboru prizvaní všetci úradní referenti, v ktorých oblasti sa koná, ako aj d’alší úradníci krajinského úradu, ktorých určil krajinský prezident. Zasadania krajinských výborov preto naozaj mohli poskytovat' vhodnú platformu pre stretnutia úradníkov s politikmi.

Zákon o organisaci politické správy napokon umožňoval, aby sa niektorí úradníci mohli (resp. na žiadost' museli) zúčastňovat' aj na rokovaniach krajinského zastupitel'stva. Nemuselo íst' len o úradníkov krajinského úradu, ale krajinský prezident mohol na zasadnutie pozvat' aj úradníkov samostatných odborných úradov, ktoré pôsobili v krajine. ${ }^{53}$ Krajinskí poslanci sa teda s úradníkmi mohli stretávat’ aj na širšom fóre.

Konfrontácia občianskeho prvku a zástupcov štátu je napokon charakteristická pre celý proces reformy verejnej správy v 20. rokoch 20. storočia. Proces poštátnenia vnútornej správy, ktorý sa realizoval nahradením dovtedajších autonómnych prvkov z čias monarchie župami a neskôr krajinami, bol vyvážený širokou účast'ou občianstva v zastupitel'ských zboroch. ${ }^{54}$ Zástupcovia štátu však boli prítomní aj v týchto zoskupeniach. Tvorili jednak predsedníctvo (župan, krajinský prezident), na druhej strane sa ich zúčastňovala aj byrokracia (ako referenti). Tým došlo k „organickému zlúčeniu samosprávy so štátnou správou“v Č́SR. 55

\section{Rokovanie krajinského výboru}

Jedna kapitola Demokratov sa odohráva priamo na zasadnutí krajinského výboru. Jesenský detailne opísal všetky nuansy rokovania výboru a jeho právomoci. Krajinský výbor zasadal v budove Krajinského úradu (dnešná budova Filozofickej fakulty Univerzity Komenského v Bratislave), čo zodpovedá zneniu ust. § 16 novelizovaného župného zákona, podl'a ktorého sa krajinský výbor schádzal na pozvanie krajinského prezidenta do sídla krajinského úradu, kedykol'vek to bolo potrebné, najmenej však raz za mesiac.

Zasadacej miestnosti dominoval stôl v tvare rímskej jednotky (I). Kým na jednom konci stola „boli kopy písem v tvrdých, červenkastých obaloch, pripravené na referovanie“, druhý koniec rímskej jednotky bol určený pre krajinského prezidenta a jeho dvoch viceprezidentov. Pred každým kreslom sa čnel dodatočný denný program, biely papier s ceruzkou a po štyroch prísediacich rozdali na stôl škatule cigariet a popolničky z modrianskej keramiky. Dlhý rad sedadiel po bokoch miestnosti vyplnili úradníci, ktorí „,mali rozdelené veci tak, že o hornej čiastke mosta prednášal jeden, o spodnej druhý, o potoku pod mostom tretí, o brehu štvrtý a o ceste na moste piaty. Preto ich bolo tol'ko. Pritom všetkom najviac miesta

52 Vládne nariadenie č. 98/1928 Zb. z. a n. zo dňa 28. 6. 1928, ktorým sa vydávajú rokovacie poriadky pre krajinské zastupitel'stvá, krajinské výbory, okresné zastupitel'stvá a okresné výbory na Slovensku a Podkarpatskej Rusi.

53 § 18 Rokovacieho poriadku pre krajinské zastupitel'stvá podl’a cit. vládneho nariadenia č. 98/1928 Zb. z. a n.

54 To zodpovedá aj inštrukcii v § 86 Ústavnej listiny, podl'a ktorého „,v nižších státních úřadech správních budiž podle možnosti zastoupen živel občanský a budiž postaráno při správních úřadech o nejvydatnější ochranu práv a zájmů občanstva“. Pozri k tomu: MATĚJKA, J. Principy organisace veřejné správy. Praha: Knihovna Sborníku věd právních a státních, 1938, s. 30

55 LAŠTOVKA, K. Nástin župního zř́zení. In: Sborník věd právních a státních, roč. 20. Praha: Bursík \& Kohout, 1920, s. 31-32. K samotnému poňatiu samosprávy pozri: SISKOVIČ, Š. Teória samosprávy v prvej ČSR. In: LACLAVÍKOVÁ, M. - ŠVECOVÁ, A. - VYŠNÝ, P. (eds.): Quid leges sine moribus? Metamorfózy vývoja štátu a práva v dejinách. Trnava: Trnavská univerzita, Právnická fakulta, 2014, s. 175. 
na dlhom zelenom stole zaberali žiadosti o podpory, prosby o odpustenie krajinských daní a pravidlá o vyberaní dávok. “56

Každý člen výboru sa zapísal do prezenčnej listiny. Obdobie do začatia oficiálneho rokovania využívali spravodajcovia na vyžiadanie si podpory pre svoje návrhy. Po príchode krajinského prezidenta ako predsedajúceho sa výborníci usadili na svoje miesta. Po otvorení zasadnutia predsedajúci zistil počet prítomných za účelom overenia uznášaniaschopnosti. Predseda oznámil, „kto podpísal predošlú zápisnicu“, a navrhol nových overovatel'ov zápisnice pre túto schôdzu. Následne podal informáciu o pozvaniach, ktoré boli doručené krajinskému výboru... šlo o „rozličné národopisné výstavy, manifestácie za mier, čajové večierky ženskej národnej rady“ a pod. „Ustálili, že na pozvanie sa pošle zvýšené vstupné, a kto by mal vôl'u, nech ide na vlastné trovy." V d'alšom kroku prešli na vybavovanie st'ažností a interpelácií, no našt’astie sa na túto schôdzu žiadne nepredložili. „Potom čítali, kol'ko má krajina miliónov dlhu, hotových peňazí a požiadaviek a kol'ko stovák nevybavených aktov.“"57

Pred otvorením denného programu ešte predsedajúci vyzval prítomných, aby sa vyjadrili k iným naliehavým problémom. Do rozpravy sa prihlásil koreferent sociálnych vecí, socialista Mangora. Oboznámil prítomných, že mu bol doručený list, ktorý sa zmieňoval o katastrofálnych hmotných podmienkach a zlom zaobchádzaní s chovancami v ústave pre duševne úchylné deti Azyl. ${ }^{58}$ Debata o tejto záležitosti trvala viac ako hodinu. V jej priebehu vyšlo najavo, že podobný list bol doručený viacerým členom výboru a aj d'alším inštitúciám. Vykonané viacnásobné kontroly však preukázali, že listy sa v prevládajúcej miere nezakladali na pravde.

No i napriek tomu sa výbor uzniesol na tom, že „,dozor nad ústavom má mat' obvodný lekár, hoci je tam lekár ústavu, ale nebude škodit', ked' sa i notár kedy-tedy obzrie, čím sa nedotýka dozorné právo okresného lekára a krajinského zdravotného šéfa...“. Okrem toho, do ústavu vyslali „,komisiu výborníkov s odborníkmi a do kuratória, ktoré ústav spravuje, dvoch členov z výboru, ked’že krajina ústav podporuje...". Zároveň výbor pokladal za nevyhnutné ,vystopovat', kto písal osočujúce listy, a zistit’, či je to nie intriga personálu proti vedúcim alebo vedúcich proti personálu, či pisatel' nechce niekoho vytisnút', a sám sa vtisnút'...".59

Čo sa týka vytvorenia osobitnej komisie, organizačný zákon fakultatívne umožňoval, aby krajinský výbor navrhol zastupitel'stvu zriadenie krajinskej komisie pre konkrétny ústav alebo podnik. Pozostávala z členov zastupitel'stva a d'alších občanov s pasívnym volebným právom do krajinského orgánu. ${ }^{60} \mathrm{~V}$ praxi sa na Slovensku naozaj vyskytli komisie vel'mi špecifického zamerania, napr. krajinská komisia pre správu lanovky na Lom-

56 JESENSKÝ, Próza Janka Jesenského, s. 656.

57 JESENSKÝ, Próza Janka Jesenského, s. 658-659.

58 Termín, „duševne úchylné diet'a“ (rozumej abnormálne) bol bežne používaným odborným výrazom. Pozri: VACULÍK, J. Sociální péče o děti a mládež za první ČSR. In: ŘEHULKA, E. (ed.). Výchova a péče o zdraví. Brno: Masarykova univerzita, 2011, s. 40.

59 JESENSKÝ, Próza Janka Jesenského, s. 666.

60 § 28 novelizovaného župného zákona v znení zákona č. 125/1927 Zb. z. a n. Zákon rozoznával zriadenie obligatórnej komisie pre správu sliezskych podnikov - ako jednu z podmienok zjednotenia Moravy a Sliezska do spoločnej krajiny - a vytvorenie fakultatívnych komisií pre každú krajinu. V pôvodnom župnom zriadení muselo každé zastupitel'stvo zriadit' obligatórne finančnú komisiu podl'a $§ 49$ a d'alšie fakultatívne komisie podla $\S 28$ pôvodného župného zákona (126/1920 Zb. z. a n.). 
nický štít, komisia pre dozor nad internátom Dr. Rumana v Košiciach, či komisie pre jednotlivé krajinské nemocnice. ${ }^{61}$ Určitá miera hypertrofie je zretel’ná v reálnom živote aj v jeho literárnom stvárnení...

V súvislosti s tým, aby sa o kauze nezačalo písat' v novinách, predseda predniesol: „Z výborovej schôdzky sa nesmie nič vynášat'. To, čo sa tu narodilo, musí tu i umriet', lebo schôdzky výboru sú neverejné.“ Poslanec Mangora mu však protirečil: „Neverejné, ale nie tajné.“ A tak ,povstala otázka, čo je neverejnost’ a čo tajnost’. Nemohli sa dohodnút'. Na návrh dr. Rubára otázka sa musela postúpit' na riešenie univerzitnému profesorovi Vrabkovi, právnemu odborníkovi.“62 Skutočnosti zodpovedalo, že podl’a $§ 27$ novelizovaného župného zákona a $§ 10$ Rokovacieho poriadku pre krajinské výbory boli schôdze týchto telies neverejné. Rokovací poriadok vymedzil prítomnost' d'alších osôb na rokovaní demonštratívnym výpočtom, pričom išlo najmä o skôr uvedených úradníkov.

Než sa krajinský výbor dostal k prerokovaniu jednotlivých bodov denného programu, odzvonila jedna hodina. Mnohí výborníci z vidieka chceli odíst' už o pol tretej, aby budúci týždeň stihli príst' na zasadanie krajinského zastupitel'stva. Z toho dôvodu zasadnutiu už nevenovali vel'kú pozornost' a všetko sa usilovali čo najrýchlejšie schválit’. „Spravodajcovia sa menili, dvíhali sa a sadali ako osoby v spevohre Svätopluk, raz na tom vŕšku, raz na druhom... prevrátili krajinskú kasu a začali sa sypat' tisícky, desat'tisícky, stotisícky... Nik nebránil podporám historickým, archeologickým, prírodovedeckým, astronomickým, etnografickým... Prešla i hlístová akcia i škodlivý chrobák sosnokaz obecný. Nezadrapil sa nikto do Rol'níckej osvety, ani do Sociálnej akadémie, ani do Klerikálnej kultúry, ani do Priatel'ského spolku s kultúrou SSSR..."63 Inde dotovali zábavu na zjazde abstinentov, financovali cestu bratislavských krajčírov na kurz do Paríža, poskytli subvenciu na turistické zväzy, tatranské chaty, kongregácie, útulne, ba podporili aj židovský sociálny spolok (na Petrovičovo rozhorčenie), či Národnú akadémiu (myslí sa Matica slovenská), obvinenú na zasadnutí z presadzovania autonomistických snáh. ${ }^{64}$ „Z Akadémie vychádzajú samé očist'ovacie aféry, ktoré ju zvrhnú na ,čistiaci ústav'. Raz čistia krajinu od Čechov, raz našu reč od čechizmov, raz našu rasu od Češiek. A my sme národ v jednom opasku s dvoma nohami. Páni moji!“65

Z právneho hl'adiska sa mala každá krajina starat' o zdravotné, sociálne, hospodárske, humanitárne, dopravné a kultúrne potreby svojich obyvatel'ov, pokial' presahovali záujem obce alebo okresu, no nemali celoštátnu dôležitost'. ${ }^{66}$ Toto poslanie napĺn̆ala primárne tým spôsobom, že sama zakladala ústavy, podniky a d’alšie inštitúcie, ktoré boli spôsobilé podporit' vytýčené ciele. Sekundárne mohla finančne podporovat' (subvencovat') aj d’alšie ústavy a inštitúcie, ktoré boli síce zriadené iným subjektom, ale sledovali rovnaký

\footnotetext{
61 SCHELLE, $c$. d., s. 293.

62 JESENSKÝ, Próza Janka Jesenského, s. 667.

63 Tamtiež, s. 670.

64 Podl'a skutočnej udalosti. Jesenský písal v liste: „na výbore Matici neodhlasovali podporu. Slováci, ked’ na podporu chovu mačiek sú hotoví odhlasovat', čert vie kol'ko. Matica svoju subvenciu síce dostane, ale i tak sa výbor na veky kompromitoval podl'ahnúc akejsi závistlivej intrige. To si neodpustím, až príde rad na opisovanie týchto krajinských schôdzok.“Porovnaj: List J. Jesenského A. Mrázovi zo dňa 15. 4. 1935. Pozri: PETRUS, Vzájomná korešpondencia Janka Jesenského s Andrejom Mrázom, s. 51.

65 JESENSKÝ, Próza Janka Jesenského, s. 673.

66 § 30 zákona č. 126/1920 Zb. z. a n. v znení zákona č. 125/1927 Zb. z. a n.
} 
ciel'. ${ }^{67}$ Ďalej sa krajina mala zúčastňovat' na financovaní projektov v jednotlivých okresoch a obciach, čo zdôraznilo aj ust. § 11 ods. 3 zákona o novej úprave finančného hospodárstva zväzkov územnej samosprávy, podl'a ktorého krajiny boli povinné podporovat' nižšie samosprávne zväzy v plnení mimoriadnych úloh (stavba škôl, dobročinných ústavov, ciest, mostov, vodovodov), najmä ak daná úloha presahovala finančné možnosti nižšieho zväzku. ${ }^{68}$ Hoci realizáciou hospodárskej pôsobnosti krajiny bolo poverené predovšetkým krajinské zastupitel'stvo, nemožno opomínat', že krajinský výbor pripravoval návrhy na rokovanie krajinského zastupitel'stva a kontroloval výkon krajinského hospodárstva. ${ }^{69}$

Jesenský zdôrazňuje nehospodárne nakladanie s krajinskými zdrojmi, nezáujem členov výboru o skutočnú odôvodnenost' finančnej podpory, na druhej strane však v priebehu deja preniká do popredia aj prehnaná byrokratická úzkostlivost' a formalizmus. Obšírna diskusia o nájdení dvoch vší v Ústave pre duševne úchylné deti vyústila do prijatia viacerých „naliehavých opatreni“, kým nakladanie s miliónovými hodnotami prešlo bez povšimnutia. Ide o satiru na byrokraciu, na zbytočné schôdzovanie, no neobmedzuje sa len na úradníkov, ale v prvom rade karikaturizuje „,demokratické“ politikárčenie. ${ }^{70}$

Podobná nedbalost' je však o to pozoruhodnejšia, že na inom mieste Jesenský spomína osobitné „úsporné oddelenie“ krajinského úradu s osobitným šéfom (v reálnom živote ním bol sám), ${ }^{71}$ „lebo ved’ krajinský úrad je sedemdesiatsedem okresných úradov. Tu je najviac úradníkov, najviac čísel, najviac atramentu a papiera, a tak i najväčšia opatrnost', aby sa zamedzil sklon k mrhaniu štátneho majetku. Opatrnost' išla tak d'aleko, že podpisovat' dlhé mená bolo zakázané, iba ak skratkou... "72 S výnimkou prezidentovej kancelárie upratovačky nemali zbytočne drat' prachovky a najlepšie by bolo, keby prezident nahradil auto velocipédom. ${ }^{73}$

\section{Vol’by do Národného zhromaždenia a úloha jeho poslancov (literárne humoresky o vzt’ahu práva a politiky)}

Politika býva definovaná ako istá forma umenia, ktorá vyžaduje od svojho tvorcu značnú mieru skúseností, schopností a vedomostí. ${ }^{74} \mathrm{~V}$ Jesenského románe nám o svojej empírii zreferoval predseda agrárnej strany: „V mocenskej politike... je každá sentimentalita vylúčená a každá krest’anská morálka dávno odparentovaná... Naším bohom je predovšetkým moc. Len kto má moc, má právo byt' chvíl'kami slabý, ústupčivý, odpúšt'ajúci, milujúci. I pánboh to len preto káže, lebo je už mocný... K moci vedie tisíc ciest a chodníkov bezprávia a násilností. Po týchto cestičkách a chodníčkoch musíme kráčat' vol'ky-nevol'ky, ak chceme príst' k moci... Ako politik nemôžeš uznávat’ ani trestný zákonník. Ked' ide

LAŠTOVKA, K. Samospráva: Země. In: HÁCHA, E. a kol. (eds.). Slovník veřejného práva československého. Svazek IV. (S-T). Praha: Eurolex Bohemia, 2000, s. 83.

Zákon č. 77/1927 Zb. z. a n. o nové úpravě finančního hospodářství svazků územní samosprávy v znení zákona č. 169/1930 Zb. z. a n.

§ 49-50 zákona č. 126/1920 Zb. z. a n. v znení zákona č. 125/1927 Zb. z. a n.

ROZNER, c. d., s. 537.

Pozri aj: Rozhodnutie Krajinského úradu v Bratislave zo dňa 14. júla 1928 č. 5000 prez. o rozvrhu agendy a práce krajinského úradu v Bratislave.

JESENSKÝ, Próza Janka Jesenského, s. 417-418.

Podl'a Jesenského denníka. Pozri: CHORVÁTH, c. d., s. 498.

WEYR, F. Politika. In: HÁCHA, E. a kol. (eds.). Slovník veřejného práva Československého. Svazek III $(P-\check{R})$. Brno: Polygrafia, 1934, s. 201. 
o moc, o vládu, je dobrá i zrada i falšovanie peňazí, klam, krádež, lúpež, vražda. Všetky tieto trestné činy, ak sa nimi môžeš dostat' k moci, sú oprávnené, a trestuhodné sú len do tých čias, kým si nie pri moci; ked’ si nimi dosiahol moc, premenia sa na slávne činy, na zásluhu, ako ked’ čarodejník spraví z tmavej šatôčky zelenú... Z nemravných našich činov spravíme politickým komediantstvom činy nevinné, záslužné, vlastenecké, z perdít panenky, z čertov anjelov." 75

Podobné stanovisko nie je len odrazom rýdzeho machiavellimu. Aj Max Weber zastával stanovisko, že politik sa usiluje predovšetkým o moc. Moc mu slúži bud' ako prostriedok na presadenie vyšších ciel'ov alebo je jeho motiváciou len samotný pocit moci. Už v časoch prvej republiky bola známa Weberova definícia politiky, podl'a ktorej je iba snahou získat' podiel na moci alebo ovplyvňovat' rozdelenie mocí. ${ }^{76}$ Podobné mocenské postoje politických strán v prvej republike a ich bezohl'adný stranícky zápas o moc sa stali jedným z hlavných problémov československej demokracie. Otázka morálky hrala často vedlajšiu úlohu. ${ }^{77}$

Najt'aživejším obdobím v živote politika však bol čas zostavovania kandidátnych listín pred vol'bami. Jesenský detailne vykreslil t’ažobu, ktorá sprevádzala tento proces, pričom zdôraznil, že: „menia sa len niektorí kandidáti. Vodcovia sa nemenia. Oni pevne sedia, sedeli a budú sediet' v parlamente, v ministerských kreslách a na kandidátkach. Ich nemožno nahradit', čo by im narástla šedivá brada po topánky... Bolo by to hriechom, lebo oni sú rozumom, otcom, svedomím a niekedy i kliatbou národa, a ani rozum, ani otec, ani svedomie, ani kliatba nestarne... Menia sa len tí, čo nevedú. Tí pri každých vol'bách akoby išli na smrt'. Nikdy nevedia, či dostatočne chránili záujmy strany a preto či ich netreba zamenit' mladými, agilnými straníkmi..."78

Na tomto podklade Jesenský vzniesol úvahu, či bolo vôbec potrebné znášat' finančné náklady na realizáciu volieb, ked' sa možno rovno spýtat' politických vodcov, ako je potrebné prerozdelit' moc v štáte. Dospieva však k záveru, že vol'by sú predsedom politických strán vlastne užitočné, lebo plnia kontrolnú funkciu voči ich vlastným poslancom. Na príklade bohatej kazuistiky načrtáva možnosti, ako poslanec mohol poškodit' záujmy strany. Ide o širokú škálu previnení od neúcty k straníckym stúpencom až po také zásadné taktické chyby, že l'udovec nechodil do kostola a komunista do krčmy.

Po zostavení kandidátok začali nádejní poslanci agitovat’ v rôznych kútoch Slovenska. Jesenského Demokrati poskytujú širokospektrálny náhl'ad do problematiky vedenia volebnej kampane v časoch prvej republiky, od spievania volebných veršovačiek, až po deklarovanie volebných sl’ubov. ${ }^{79}$ Vyskytli sa aj prípady volebnej korupcie: „Kurz vóta je vel'mi vysoký. I to len u Cigánov“ (v Bánovciach kvôli kňazovi Turčekovi). Zato V Svätom Ondrejovi agrárnici „dávali závdavok po štyroch korunách za hlas, štyri mali dostat’ v deň

75 JESENSKÝ, Próza Janka Jesenského, s. 568-570.

76 WEBER, M. Gesamtausgabe (Wissenschaft als Beruf; Politik als Beruf). Tübingen: J. C. Mohr, 1992 , S. 212.

77 K tejto téme pozri BRTKO, R. Vývoj vzt’ahu práva a morálky v európskom priestore. Acta Facultatis Iuridicae Universitatis Comenianae, 2015, roč. 34, č. 1, s. 22-23. Taktiež BRTKO, R. Spravodlivost', platnost' a efektivita právnych noriem v kontexte vzt'ahu medzi ,ius naturale“ a ,ius pozitivum“. In: Právo v priestore a čase: Zborník. Bratislava: Atticum, 2014, s. 33 a nasl.

78 JESENSKÝ, Próza Janka Jesenského, s. 576-577.

79 Ku komparácii s historickým stavom pozri: OSYKOVÁ, L. Volebné kampane politických strán na Slovensku počas 1. ČSR. Bratislava: Veda, 2012, s. 125-130. 
volieb a štyri po odhlasovaní a spočítaní výsledkov“ (agrárnici kandidovali pod číslom štyri). ${ }^{80} \mathrm{~V}$ iných dedinách chodili štyria čižmári a brali mieru voličom na čižmy. ${ }^{81}$

Napriek tomu sa „národ priučil politicky mysliet'. Už sa nestávalo ako predtým, že by bol volič dvadsat' papierikov hodil do urny a jeden do koša, stojaceho pri urne, ani to, že by sa bol niektorý zblaznel za stenou, alebo že by sa bol niektorý začal zobliekat', mysliac si, že ked' je sám, musí byt' ako doma... minulost’ou bolo, že babky, ked' im ukázali, kam majú hodit' svoj hlas, sadali na urnu, a nemajúc svoje svedomie čisté, nazdali sa, že budú vypočuté, akoby pred súdom. “82

Petrovič sa v rámci kandidátnej listiny dostal na zvolitel'né miesto a vo vol’bách bol úspešný. Stal sa poslancom Národného zhromaždenia. Ked’že „byt' dvojakým poslancom sa zakazuje, musel povedat' úprimné zbohom svojej menšej krajine“". ${ }^{83} \mathrm{~V}$ dôsledku ustanovení o inkompatibilite funkcií už nemohol d’alej pôsobit' ako krajinský poslanec. Vyplývalo to najmä z ust. § 20 ods. 6 Ústavnej listiny, podl'a ktorého členovia Ústavného súdu, prísediaci Volebného súdu a členovia župných (t. j. krajinských) zastupitel'stiev nemohli byt' zároveň členmi Národného zhromaždenia. ${ }^{84}$ Podobnú klauzulu obsahovalo aj ust. $\S 6$ ods. 5 zákona č. 330/1920 Zb. z. a n. v znení zákona č. 126/1927 Zb. z. a n., ktorý ustanovoval, že ak sa člen krajinského zastupitel'stva stal poslancom Národného zhromaždenia, ipso facto strácal členstvo v krajinskom zastupitel'stve.

V tomto období si však Petrovič počínal príliš svojvol'ne. Ešte pred vol'bami vystúpil s obhajobou Národnej akadémie na krajinskom výbore. Potom s vel'kou slávou rečnil na zhromaždení l’udáckej mládeže, ktorá protestovala proti premietaniu ,židovského“ filmu o Golemovi. Na rokovaní Správnej rady Gazdovskej banky sa postavil proti odloženiu vymáhania dlžôb od malých rol'níkov. Obhajoval starého Rozvalida v spore s bankou, ktorú ovládali l’udia z jeho vlastnej strany. „Aký je to straník? Advokát, a nie poslanec!“‘ preblesklo mysl'ou bývalému poslancovi Radlákovi, ktorý na úkor Petroviča nebol opätovne zvolený do parlamentu. „Malý výhonok svojej vôle naočkujem do konára vôle pána predsedu. Ak sa tu ujme, naočkuje sa do stromca prezídia. Ak sa chytí a vyklíči na strome strany, vec je hotová. Volebný súd sú už nožnice, ktoré odštiknú nepotrebný uschnutý konár a nahradí sa sviežou vetvičkou Radlákovho mandátu!'‘85

Hoci predseda strany najskôr Petroviča bránil, zdá sa, že Petrovič opät’ neustrážil svoju výrečnost' a predniesol d'alší z tematicky ladených prejavov, ktoré nevyhovovali rázu jeho vlastnej strany. To už bolo privel'a. „I poslanca volajú na zodpovednost' ako hocijakého komisára... Ked' sa odvolával, že jeho na miesto poslanca postavila vôl'a l’udu, povedali

80 JESENSKÝ, Próza Janka Jesenského, s. 691; s. 726. K trestnoprávnemu a kriminologickému fenoménu korupcie pozri: BELEŠ, A. Pojem úplatok - z pohl'adu zákona a aplikačnej praxe. Acta Facultatis Iuridicae Universitatis Comenianae, 2016, roč. 35, č. 2, s. 5. Pozri tiež: BELEŠ, A. Korupcia v súvislosti s obstarávaním veci všeobecného záujmu. Justičná revue, 2017, roč. 69, č. 8-9, s. 1112-1116.

81 Jesenského obraz volieb korešponduje s viacerými skutočnými udalost’ami. Kým agrárnici boli na Slovensku vnímaní ako úplatkári s vagónmi petroleja, či soli, l'udáci sa zásadne dotýkali zbožnosti človeka - ako sa vraví v románe: „Panenka Mária sa bude dívat’ za volebnú plentu, či volíš správne.“ K tejto volebnej kazuistike na Slovensku pozri: OSYKOVÁ, L. Volebná kampaň L'udovej strany pred parlamentnými vol'bami v 20. rokoch 20. storočia. Historický časopis, 2010, roč. 58, č. 2, s. 235-236.

82 JESENSKÝ, Próza Janka Jesenského, s. 736.

83 Tamtiež, s. 739.

84 BAXA, B. Stručný výklad Ústavy republiky Československé. České Budějovice: Ján Svátek, 1920, s. 33.

85 JESENSKÝ, Próza Janka Jesenského, s. 771. 
mu, že je to na súd, ktorý takú vôl'u zo snemu vypichá, lebo do parlamentu patrí len uniformovaná stráž, ktorú robí strana podl’a rozkazu velitel'a." ${ }^{86}$ Napokon Petrovičovi predložili „,papierik, na ktorom bolo, že ak pán poslanec nechce súd a úradné potvrdenie o tom, že voliči vyvolili nízkeho a nečestného človeka za svojho zástupcu do snemu, podrobuje sa vo všetkom disciplíne strany - tak mu pánboh pomáhaj! Pán poslanec podpísal. Tým sa zachovala platnost' druhého papierika, takzvaného poslaneckého mandátu... Byt' straníkom teda znamená dovolit' si vyvlastnit' svoju slobodu presvedčenia, stat' sa otrokom, ktorý musí konat' to, čo chce jeho pán - strana. “87

Načrtnutý mechanizmus straty mandátu sa opieral o ustanovenie § 13 zákona č. 125/1920 Zb. z. a n. o volebním soudě. Podl'a neho bolo možné dodatočne pozbavit' poslanca Národného zhromaždenia jeho mandátu, ak z nízkych alebo nečestných dôvodov prestal byt' členom strany, ktorá ho umiestnila na svoju kandidátnu listinu. Začatie konania mohol iniciovat' nielen predseda Národného zhromaždenia, ale aj dotknutá politická strana, ktorá tohto poslanca zaradila na kandidátsku listinu. ${ }^{88}$

Pri posudzovaní skutkového stavu bolo irelevantné, či poslanca zo strany (resp. z poslaneckého klubu) vylúčili alebo z nej vystúpil sám. Podstata konania sa mala koncentrovat' na preukázanie „,nízkych alebo nečestných“ dôvodov, ked’že práve to predstavovalo garanciu toho, aby poslanec nestratil mandát len v dôsledku rozhodnutia politickej strany. ${ }^{89}$ V enunciáte rozhodnutia Volebný súd mal zároveň konštatovat', že na takto uprázdnený mandát nastupuje náhradník v súlade so systémom viazaných kandidátnych listín. ${ }^{90}$

„Nízke alebo nečestné konanie“ sa viazalo na najmä problematiku politickej morálky. Malo sa prejavovat' vo vzt'ahu poslanca k jeho strane. Nemožno ho primárne spájat' ani s odsúdením poslanca za trestný čin, ani s vyhlásením konkurzu na jeho majetok, čo bolo legislatívne upravené $\mathrm{v}$ osobitnej kategórii, $\mathrm{v}$ rámci ktorej mandát zanikal v dôsledku straty volitel'nosti. ${ }^{91}$ Disjunkcia „,nízke alebo nečestné“ poukazuje na alternatívnost' oboch možností, ked’že napríklad vedomé nesplnenie záväzku, ktorý poslanec dal svojej strane bolo nečestné, ale nemuselo byt' automaticky aj nízke. ${ }^{92}$

Judikatúra volebného súdu celkom jasne naznačila, že účelom tohto ustanovenia je zachovanie (,,petrifikácia“) pôvodného pomeru politických strán v zákonodarnom zbore počas určitého volebného obdobia. Opustením politickej strany strácal príslušník všetky funkcie, výhody a práva, ktoré sa viazali na jeho členstvo v strane, čo sa malo vzt'ahovat' aj na poslanecký mandát, ak jeho kandidatúra bola motivovaná práve príslušnost'ou

86 JESENSKÝ, Próza Janka Jesenského, s. 792.

87 Tamtiež, s. 793-794.

88 PEŠKA, Z. Ztráta mandátu výrokem volebního soudu. In: Právny obzor, roč. 10. Bratislava: Právnická jednota na Slovensku, 1927, s. 50.

89 HOETZEL, J. Soudni kontroly veřejné správy. Praha: Všehrd, 1924, s. 52.

90 Tamtiež, s. 56.

91 Podl'a zákona č. 123/1920 Zb. z. a n., kterým vydává se řád volení do poslanecké sněmovny pasívne volebné právo strácal ten, kto bol vylúčený z práva volit', t. j. bol vyškrtnutý zo stáleho voličského zoznamu podl'a zákona č. 663/1919 Zb. z. a n. o stálých seznamech voličských. Tieto následky nastávali najmä v prípade vyhlásenia konkurzu alebo odsúdenia právoplatným rozsudkom trestného súdu za taký zločin, prečin alebo priestupok, s ktorým právny poriadok spájal stratu volebného práva. Preto treba zdôraznit’, že nie všetky trestné činy boli späté aj s následkom straty volebného práva.

92 Zákon obsahoval pôvodne spojku a. Uvedené znenie bolo zakotvené až novelou č. 145/1924 Zb. z. a n. 
$\mathrm{k}$ tejto strane. ${ }^{93} \mathrm{~V}$ praxi Volebného súdu sa za konformné pokladali aj reverzy, ktorými sa kandidát vopred zaväzoval vzdat' sa mandátu v prípade, ak stratí dôveru svojej strany. ${ }^{94}$ Súd ich interpretoval ako platnú dohodu (záväzok) poslanca so svojou politickou stranou. Žaloba politickej strany za týmto účelom postačovala na stratu mandátu bez toho, aby sa súd zaoberal zákonnými dôvodmi. ${ }^{95}$

Z toho dôvodu zákon o Volebnom súde naozaj neposkytoval poslancom účinnú ochranu, ba sa „stal účinným nástrojom zabezpečovania plnenia príkazov politických strán poslancami““.96 Každý poslanec bol v zásade dopredu viazaný hlasovat' tak, ako to vyžadovali záujmy a ciele politickej strany. Ak odmietol, vystavoval sa nebezpečenstvu, že ho stihne stranícky a politický trest. V prvej ČSR postihol takýto osud hned' viacerých poslancov, jedným zo slávnejších bol prípad Bohuslava Vrbenského, ktorý odmietol hlasovat' za zákon o ochrane republiky. ${ }^{97}$

Hrozbe konaním pred Volebným súdom možno prikladat’ náležitú vážnost'. Petrovič sa podrobil dôvodne. To všetko však poukazuje na iluzórnost' zákazu imperatívneho mandátu poslanca podl'a ust. § 22 ods. 1 Ústavnej listiny, hoci už starší akademici uznávali, že v praxi bude táto požiadavka vel'mi t’ažko vykonatel'ná. ${ }^{98}$ Preto možno kúsok relevancie pririect' aj tomuto tvrdeniu z románu: „Byt’ zákonodarcom je otrocká robota, nie generál, ale kôň v cirkuse. Nesmieš vybočit' z ohrady, ináč je hned' nešt'astie... Hned' si nespol'ahlivý, nízky, nečestný. Prídeš pred súd, ktorý Ťa celkom iste zbaví milej dôvery voličstva. Hlasuje na Teba stotisíc voličov, a mandát Ti vezme jeden prezident s dvanástimi prísediacimi““(t. j. Volebný súd). ${ }^{99}$

Práve preto je najväčšou cnost'ou politika vernost' straníckemu predsedníctvu. Jesenský to dokázal naznačit' v prejave predsedu demokratickej politickej strany, ktorým reagoval na nespokojnost' straníckych funkcionárov pri zostavovaní kandidátnej listiny. Ich odpor prekonával výzvou, aby ich rady opustil ten, komu sa tieto rozhodnutia nepáčia, lebo „disciplína musí byt' i v demokracii. Demokracia nie je bezuzdnost’. Cválajúce kone na poli... disciplína v demokracii, demokratická diktatúra, vôl'a väčšiny, ktorej sa musí každý podrobit'. Tie rozkazy dáva strana, a nie my, l'ud. Strana je ten inžinier, ktorý putná bezuzdnú rieku... Strana je diktátorom, nie jednotlivec, a ked' je ten jednotlivec i vodcom, vodca má ústa strany, ktoré vypovedia, čo strana chce." ${ }^{100}$

\footnotetext{
93 WEYR, F. Soustava československého práva státního. Druhé vydání. Praha: Fr. Borový, 1924, s. 144.

94 HAPLA, M. Geneze vázaného mandátu v prvorepublikovém Československu. Časopis pro právní vědu a praxi, 2009, roč. 17 , č. 2, s. 127.

95 BAXA, B. Parlament a parlamentarism. I. Díl: Parlament, jeho vývoj, složení a funkce. Praha: Jan Košatka, 1925, s. 253-254.

96 LACO, K. Ústava predmníchovskej ČSR a ústava ČSSR. 1. Čast'. Bratislava: Vydavatel'stvo Slovenskej akadémie vied, 1966, s. 452-453.

97 SIVÁK, F. Volebné právo a prvé parlamentné vol'by v Československu po roku 1918. In: Acta Facultatis Iuridicae Universitatis Comenianae, 1993, roč. 15. Bratislava: Univerzita Komenského, 1994, s. 134.

98 VAVŘÍNEK, F. Základy práva ústavního. Díl I. Praha: Všehrd, 1930, s. 91.

99 JESENSKÝ, Próza Janka Jesenského, s. 590.

100 Tamtiež, s. 612-613.
} 


\section{Záver}

Predložená štúdia sa usilovala zachytit' skutočný stav demokracie a parlamentarizmu v prostredí prvej Československej republiky. Značný priestor bol venovaný charakteristike krajinského zriadenia na Slovensku a reforme verejnej správy v ČSR na podklade Jesenského postrehov. V tomto rámci by bolo potrebné upozornit' najmä na spolitizovanie krajinských jednotiek, ktoré mali byt' pôvodne konštruované ako odborné útvary. S tým súvisí aj nenaplnenie prvotnej idey menovacieho práva do krajinského zastupitel'stva a zneužívanie tohto inštitútu na politické účely. Jesenský rovnako poukazuje na nedostatočné vyváženie byrokracie účast'ou občianskych zborov na krajinskej úrovni. Ked’že krajiny sa vytvorili zlúčením samosprávnych jednotiek a zložiek štátnej správy, určitá implicitná duálnost' im ostala vlastná. ${ }^{101}$

Jesenský podrobil značnej kritike prax politických strán a postupný rozklad demokratických hodnôt $\mathrm{v}$ Republike, no pravý zmysel románu možno vidiet' $\mathrm{v}$ jeho pedagogických účinkoch. ${ }^{102} \mathrm{Z}$ pozícií demokratizmu, humanizmu a čechoslovakizmu Jesenský nežiadal odstránenie tohto systému, ale jeho nápravu: „chcel som dokázat', že to, čo vidíme okolo seba, nenasvedčuje demokratizácii, ale že aspoň v politických stranách panuje diktátorstvo a aktívni politici sú de facto nie slobodní l'udia. Je to teda práca za slobodu a za demokratické práva.“"103 Použitie satiry a irónie pri deskripcii predstavitel'ov demokratického režimu odôvodňoval sám Jesenský takto: „V Demokratoch som chcel opísat’ malichernosti a l'udské chyby, ktoré sa vyskytujú $\mathrm{v}$ najvznešenejšom a najlepšom človekovi práve tak, ako pri malom, úzkoprsom občanovi. Malichernost' a chyby treba bit' z lásky, a nie z nenávisti, podl'a ruského kogo l'ubl'u, togo i bju. Ak bijem niekoho v Demokratoch, to len preto, že ho mám rád.“"104 Po vydaní druhého dielu Demokratov v marci 1938 ostávalo prvej republike ešte pár mesiacov života.

101 To sa dôsledne prejavilo napríklad pri rozlišovaní samosprávnej a štátnej pôsobnosti Krajinských úradov a krajinských zastupitel'stiev. Pozri: LAŠTOVKA, K. Politické úřady. In: HÁCHA, E. a kol. (eds.). Slovník veřejného práva Československého. Svazek III (P-̌̌). Brno: Polygrafia, 1934, s. 198-200.

102 CHORVÁTH, c. d., s. 475-477.

103 List J. Jesenského A. Mrázovi zo dňa 24. 11. 1937. Porovnaj: Pozri: PETRUS, Vzájomná korešpondencia Janka Jesenského s Andrejom Mrázom, s. 85.

104 Citované z matičného časopisu „Slovensko“ podl'a: ROZNER, c. d., s. 599. 